\title{
STUDI ANALISIS PERSENTASE WASTE BESI BETON DAN FAKTOR PENYEBABNYA PADA BANGUNAN BERTINGKAT RENDAH DI JAKARTA
}

\author{
Liem Antonio Geraldi ${ }^{1}$ dan Hendrik Sulistio ${ }^{2}$ \\ ${ }^{1}$ Program Studi Sarjana Teknik Sipil, Universitas Tarumanagara, Jl. Letjen S. Parman No.1 Jakarta \\ Email: liem.325150078@stu.untar.ac.id \\ ${ }^{2}$ Program Studi Sarjana Teknik Sipil, Universitas Tarumanagara, Jl. Letjen S. Parman No.1 Jakarta \\ Email: hendriks@ft.untar.ac.id
}

Masuk: 17-01-2020, revisi: 11-02-2020, diterima untuk diterbitkan: 19-02-2020

\begin{abstract}
Waste iron material is often found in a construction project. Of course, by knowing what is the cause of waste iron material, the waste of this material can also be controlled and minimized. This research was conducted on a low rise building project in the Jakarta area and its surroundings which aims to find out what percentage volume of waste that occurs, how much loss, and causes the waste steel material. Analysis determine volume of waste and losses to find the number of concrete steel material requirements, the amount of concrete steel material purchase, and unit price of concrete iron material in a project obtained from drawings, weekly / monthly reports, budget plans, and interviews directly to the construction. To find cause of the waste carried out by distributing questionnaires to construction, the variables related to waste concrete iron such as humans, management professionalism, design and documentation, materials, implementation, and external. The results of the questionnaire will processed using the factor analysis with SPSS program in which of the six variables will be grouped based on the value of the relationship and which group of variables will play a major role in the waste of concrete iron material.
\end{abstract}

Keywords: Waste, Iron bar, Loss

\begin{abstract}
ABSTRAK
Pemborosan material besi beton merupakan suatu hal yang masih sering dijumpai dalam suatu proyek konstruksi. Tentunya dengan mengetahui apa yang menjadi penyebab dari pemborosan material besi beton, maka pemborosan material ini pun dapat dikontrol dan diminimalisir. Penelitian ini dilakukan pada proyek low rise building di daerah Jakarta dan sekitarnya yang bertujuan untuk mengetahui seberapa besar persentase volume pemborosan yang terjadi, berapa besar kerugian yang diakibatkan, dan apa saja penyebab terjadinya pemborosan dari material besi beton. Analisis yang dilakukan untuk mengetahui besar volume pemborosan dan kerugiannya adalah dengan mencari angka kebutuhan material besi beton, jumlah pembelian material besi beton, dan harga satuan material besi beton dalam suatu proyek yang dapat diperoleh dari gambar kerja, laporan mingguan/bulanan, rencana anggaran biaya, dan wawancara langsung kepada pihak pelaku konstruksi. Untuk mengetahui penyebab pemborosannya akan dilakukan dengan penyebaran kuesioner kepada pelaku konstruksi yang berisikan tentang variabel-variabel yang berhubungan dengan pemborosan material besi beton seperti manusia, profesionalitas menejemen, desain dan dokumentasi, material, pelaksanaan, dan kendala luar. Hasil dari kuesioner akan diolah menggunakan metode analisis faktor dengan bantuan program SPSS dimana dari keenam variabel tersebut akan dikelompokkan berdasarkan nilai keterkaitannya dan akan diperoleh kelompok variabel mana yang berperan besar dalam pemborosan material besi beton tersebut.
\end{abstract}

Kata Kunci: Pemborosan, Besi beton, Kerugian

\section{PENDAHULUAN}

Pembangunan kontruksi di Indonesia kian lama semakin banyak mulai dari gedung-gedung bertingkat tinggi, jembatan, jalan-jalan raya hingga tempat tinggal dan pertokoan. Dengan bertambah banyaknya proyek pembangunan di Indonesia, banyak juga pihak-pihak yang terlibat di dalam prosesnya.

Dalam prosesnya tidak luput pula dijumpainya masalah-masalah ataupun kendala yang besar maupun kecil. Salah satu permasalahan yang masih timbul yaitu ketidakefesienan pekerjaan yang dilakukan sehingga akan menimbulkan pemborosan sumber daya atau yang bisa disebut waste. Waste dapat dikatakan sebaga masalah yang utama dalam sektor konstruksi Muhwezi et al. (2012). Waste di bidang konstruksi dapat diartikan sebagai kehilangan atau kehilangan sumber daya material, waktu (berkaitan dengan tenaga kerja dan peralatan) dan modal, yang disebabkan 
oleh kegiatan yang membutuhkan biaya, langsung atau tidak langsung, tetapi tidak menambah nilai pada akhir produk untuk pengguna jasa konstruksi (Waty et al, 2018)

Permasalahan waste yang paling umum dijumpai pada konstruksi adalah waste material. Pernyataan tersebut didasari oleh Ganesan (2000) yang mengatakan bahwa material konstruksi merupakan pemegang alih terbersar dalam suatu konstruksi karena proporsinya yang sebesar 50\%-60\% dari total biaya suatu proyek.

Dalam masalah waste material ini, material besi beton merupakan salah satu penyumbang waste terbesar dalam suatu konstruksi. Hal ini diperkuat dari hasil studi kasus proyek pembangunan showroom auto 2000 di Binjai oleh Adlin et al. (2017). Dalam studi kasusnya dikatakan bahwa waste material terbesar disebabkan oleh besi beton yang berada di angka $3.69 \%$ dari volume totalnya sebesar $3139.95 \mathrm{~kg}$. Jika angka tersebut dikonversikan ke dalam biaya, total kerugian waste akibat material besi beton berkisar Rp. 31,734,000.

Oleh sebab itu perlu diperhitungkan besar volume, kerugian, dan penyebab terjadinya waste material besi beton ini agar besar waste yang dihasilkan dapat dikontrol dan diminimalisir.

\section{METODOLOGI PENELITIAN}

\section{Pengumpulan Data}

Dalam penelitian ini metode pngumpulan data dilakukan dengan 2 cara yaitu:

1. Data primer : Data yang diperoleh secara langsung yaitu berupa data kuesioner dan wawancara dengan pelaku konstruksi

2. Data sekunder : Data yang dikumpulkan dari intansi terkait yang bisa berupa RAB, Bill of Quantities, gambar kerja, laporan mingguan / bulanan, data logistik, dan data pembelian material.

\section{Pengolahan Data}

Dalam penelitian waste ini untuk menganalisa data yang telah diperoleh dibagi menjadi 2 tahap dimana tahap yang pertama untuk mengetahui besar waste yang ditimbulkan dan besar kerugian yang diakibatkan oleh waste besi beton tersebut. Tahap kedua adalah untuk menganalisa faktor-faktor penyebab terjadinya waste besi beton.

\section{Menghitung besar dan biaya waste material besi beton}

Untuk menghitung besar dan biaya waste material besi beton, diperlukan data sekunder seperti RAB, Bill of Quantities, gambar kerja, laporan mingguan / bulanan, data logistik, data pembelian material, atau wawancara langsung dengan pelaku konstruksi.

Selanjutnya dari semua data tersebut dapat diperloleh besar kebutuhan material besi dalam suatu proyek dan jumlah material besi yang datang kelapangan. Dengan perhitungan matematis sederhana sebagai rumus berikut:

$$
\text { volume waste }=\frac{Q-Z}{Z} \times 100 \%
$$

Dengan $\mathrm{Q}=$ volume material besi beton yang dating ke lapangan $(\mathrm{kg}), \mathrm{Z}=$ volume kebutuhan material besi beton.

Sementara untuk menghitung besar kerugian yang diperoleh dapat diperoleh dengan rumus berikut:

$$
\text { kerugian waste }=(Q-Z) \times Y
$$

Dengan $\mathrm{Q}=$ volume material besi beton yang dating ke lapangan $(\mathrm{kg}), \mathrm{Z}=$ volume kebutuhan material besi beton, $\mathrm{Y}$ = Harga satuan material besi beton.

\section{Analisis faktor penyebab waste}

Untuk menguji faktor-faktor penyebab waste material besi beton ini, metode penelitian yang digunakan adalah dengan program SPSS (Statistical Package for Social Science) dengan metode analisis faktor. Dengan menggunakan metode analisis faktor kita dapat mengetahui dari 6 variabel (Manusia, Profesionalitas Menejemen, Desain \& Dokumentasi, Material, Pelaksanaan, Kendala Luar) yang berperan dalam waste material besi beton ini, variable mana yang dominan untuk menjadi suatu faktor dengan mempertimbangkan nilai korelasinya sesama variabel lainnya.

Dari ke-6 variabel, dalam pembuatan kuesioner akan diberikan 2 pertanyaan untuk setiap variabel masing-masing. Jadi total pertanyaan yang diajukan akan berjumlah 12 pertanyaan dimana untuk cara penjawabannya diberikan 5 kotak yang akan memberikan penilaian akan pertanyaan tersebut. 5 penilaian tersebut adalah : (1) sangat setuju, (2) 
setuju, (3) netral, (4) tidak setuju, (5) sangat tidak setuju. Dimana jika responden menjawab selalu, maka point yang diberikan pada pertanyaan tersebut adalah 5, tetapi jika responden menjawab sering, maka point yang diberikan pada pertanyaan tersebut adalah 4 dan berlaku sedemikian pula hingga pada jawaban tidak pernah.

\section{HASIL DAN PEMBAHASAN}

\section{Perhitungan besar persentase volume waste material besi beton}

Dari data-data penelitian sepuluh proyek low rise building yang berada di Jakarta dan sekitarnya, dirangkum dalam 1 tabel dibawah berikut

Tabel 1 Hasil perhitungan beesar persentase volume waste material besi beton

\begin{tabular}{ccccc}
\hline $\begin{array}{c}\text { Nama } \\
\text { proyek }\end{array}$ & $\begin{array}{c}\text { Kebutuhan material besi } \\
\text { beton (kg) }\end{array}$ & $\begin{array}{c}\text { Material besi } \\
\text { beton yang } \\
\text { datang ke } \\
\text { lapangan (kg) }\end{array}$ & $\begin{array}{c}\text { Potensi waste } \\
(\mathbf{k g})\end{array}$ & $\begin{array}{c}\text { Persentase volume } \\
\text { waste }(\boldsymbol{\%})\end{array}$ \\
\hline Proyek A & 1753.11 & 1797.7 & 44.59 & 2.54 \\
\hline Proyek B & 1837.71 & 1901.6 & 63.89 & 3.48 \\
\hline Proyek C & 3960.97 & 4040.6 & 79.63 & 2.01 \\
\hline Proyek D & 7920.68 & 8400.6 & 479.92 & 6.06 \\
\hline Proyek E & 8776.41 & 9278.3 & 501.89 & 5.72 \\
\hline Proyek F & 22176.34 & 22705.6 & 529.26 & 2.39 \\
\hline Proyek G & 12587.52 & 13002.4 & 414.88 & 3.3 \\
\hline Proyek H & 5828.73 & 6135 & 306.27 & 5.25 \\
\hline Proyek I & 9900.48 & 10589.8 & 689.32 & 6.96 \\
\hline Proyek J & 10791.37 & 11452.7 & 661.33 & 6.13 \\
\hline
\end{tabular}

Dari hasil perhitungan tabel 1. diperoleh angka rata-rata persentase waste material besi beton pada proyek low rise building di daerah Jakarta dan sekitarnya adalah sebesar $4.384 \%$.

\section{Perhitungan Besar Kerugian akibat Waste material besi beton}

Setelah diperoleh perhitungan persentase volume waste material besi beton, barulah dapat diperoleh nilai besar kerugian yang diakibatkan oleh waste tersebut. Semua perhitungan kerugian waste material besi beton terangkum dalam table dibawah ini.

Tabel 2 Perhitungan kerugian waste material besi beton

\begin{tabular}{|c|c|c|c|}
\hline Nama proyek & Potensi waste (kg) & $\begin{array}{c}\text { Harga satuan } \\
\text { (Rp) }\end{array}$ & $\begin{array}{c}\text { Besar biaya } \\
\text { waste (Rp) }\end{array}$ \\
\hline Proyek A & 44.59 & \multirow{10}{*}{18049.14} & $804,811.15$ \\
\hline Proyek B & 63.89 & & $1,153,159.55$ \\
\hline Proyek C & 79.63 & & $1,437,253.02$ \\
\hline Proyek D & 479.92 & & $8,662,143.27$ \\
\hline Proyek E & 501.89 & & $9,058,682.87$ \\
\hline Proyek F & 529.26 & & $9,552,687.84$ \\
\hline Proyek G & 414.88 & & $7,488,227.20$ \\
\hline Proyek H & 306.27 & & $5,527,910.11$ \\
\hline Proyek I & 689.32 & & $12,441,633.18$ \\
\hline Proyek J & 661.33 & & $11,936,437.76$ \\
\hline
\end{tabular}


Dari data tabel diatas dapat dilihat bahwa besar kerugian waste material besi beton dari masing-masing proyek beragam nilainya. Jika dilihat lagi, besar kerugian waste dan potensi waste dari "Proyek Town House Sinar Indah 1", "Proyek Town House Sinar Indah 2", dan "Proyek Town House Sinar Indah 3" adalah nilai yang terkecil diantara 7 proyek lainya, hal tersebut bisa terjadi karena pencegahan waste pada ketiga proyek tersebut bisa dibilang sangat diperhatikan dan terorganisasi dengan baik sehingga menimbulkan waste dengan jumlah kecil.

\section{Analisis Faktor penyebab Waste material Besi Beton}

Dari ke 12 pertanyaan dalam kuesioner, terdapat 6 jenis variabel yaitu ada Manusia, Profesionalitas Menejemen, Dokumentasi dan Desain, Material, Pelaksanaan, dan Eksternal. Dimana dari masing-masing variabel direpresentasikan dengan 2 pernyataan yang berhubungan dengan penyebab waste besi beton. Dan jawaban dari setiap pernyataan tersebut akan mewakili poin untuk masing-masing variabel yang nilainya dimulai dari 1,00 - 5,00 yang nantinya akan dimasukan ke dalam program dan dianalisis.

Sebelum melakukan analisis faktor perlu dilakukan uji normalitas data kuesioner terlebih dahulu. Berikut adalah hasil uji normalitas dari ke-6 variabel data kuesioner penelitian.

\begin{tabular}{|c|c|c|c|c|c|c|c|}
\hline \multicolumn{8}{|c|}{ One-Sample Kolmogorov-Smirnov Test } \\
\hline & & Manusia & $\begin{array}{l}\text { Profesionalita } \\
\text { s Menejemen }\end{array}$ & $\begin{array}{c}\text { Desain \& } \\
\text { Dokumentasi }\end{array}$ & Material & Pelaksanaan & Kendala Luar \\
\hline$N$ & & 22 & 22 & 22 & 22 & 22 & 22 \\
\hline \multirow[t]{2}{*}{ Normal Parameters ${ }^{a, b}$} & Mean & 3.8864 & 2.9091 & 3.6364 & 3.3636 & 3.3864 & 2.6136 \\
\hline & Std. Deviation & 1.01103 & 1.21142 & 1.18705 & 1.26474 & 1.31775 & 1.24338 \\
\hline \multirow[t]{3}{*}{ Most Extreme Differences } & Absolute & .183 & .183 & .176 & .159 & .162 & .144 \\
\hline & Positive & .135 & .183 & 125 & .159 & .126 & .144 \\
\hline & Negative & -.183 & -.136 & -.176 & -.147 & -.162 & -.140 \\
\hline Test Statistic & & .183 & .183 & .176 & .159 & .162 & .144 \\
\hline Asymp. Sig. (2-tailed) & & $.054^{\mathrm{c}}$ & $.055^{\mathrm{C}}$ & $.076^{\mathrm{c}}$ & $.157^{\mathrm{c}}$ & $.136^{\mathrm{c}}$ & $200^{\mathrm{c}, \mathrm{d}}$ \\
\hline \multicolumn{8}{|c|}{ a. Test distribution is Normal. } \\
\hline \multicolumn{8}{|l|}{ b. Calculated from data. } \\
\hline \multicolumn{8}{|c|}{ c. Lilliefors Significance Correction. } \\
\hline \multicolumn{8}{|c|}{ d. This is a lower bound of the true significance. } \\
\hline
\end{tabular}

Gambar 1. Hasil uji normalitas

Dapat dilihat dari hasil uji normalitas pada gambar 1. diatas nilai uji Asymp. Sig.(2-tailed) pada masing-masing variabel adalah 0.054 (Manusia), 0.055 (Profesionalitas Menejemen), 0.076 (Desain \& Dokumentasi), 0.136 (Pelaksanaan), 0.200 (Kendala Luar). Sementara dasar pengambilan keputusan dalam uji normalitas adalah:

1. Jika nilai Asymp. Sig.(2-tailed) $>0.05$ maka data berdistribusi normal.

2. Jika nilai Asymp. Sig. (2-tailed) $<0.05$ maka data tidak berdistribusi normal.

Dalam penelitian ini semua nilai Asymp. Sig.(2-tailed) berada pada angka >0.05. Dengan demikian maka analisis faktor dapat dalam penelitian ini dapat dilanjutkan.

Setelah semua data terdistribusi secara normal maka langkah selanjutnya adalah memulai perhitungan analisis faktor yang meliputi uji :

1. Uji nilai Kaiser Mayer Olkin Measure of Sampling Adequacy (KMO MSA) yang nilainya harus lebih besar dari 0.50

2. Uji nilai Bartlett's Test of Sphericity (Sig.) yang nilainya harus lebih kecil dari 0.05 
3. Uji hubungan atau korelasi yang kuat antar variabel yang ditandai dengan nilai Anti-image Correlation antar variabel lebih besar dari 0.50

\section{$\Rightarrow$ Factor Analysis}

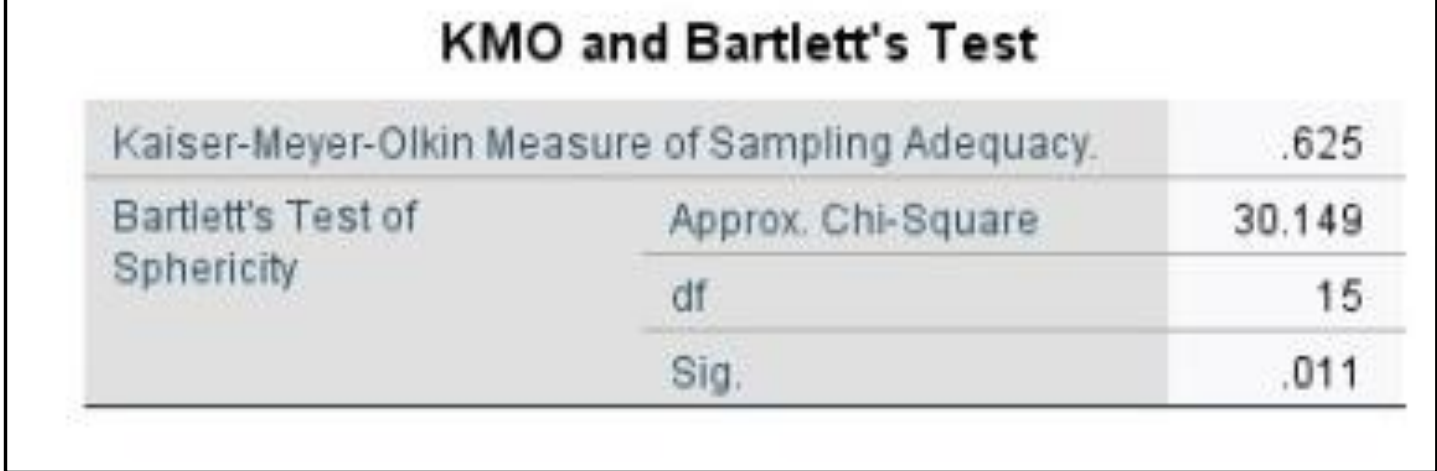

Gambar 2. Hasil KMO and Bartlerr's Test

Pada gambar diatas ini adalah data hasil perhitungan nilai Kaiser Meyer Olkin Measure of Sampling Adequacy dimana nilainya dari penelitian ini adalah 0.62 , sementara syarat untuk metode analisis faktor dibutuhkan nilai KMO-MSA lebih besar dari 0.50, maka perhitungan selanjutnya dari analisis faktor dapat dilanjutkan.

Selanjutnya adalah melihat hasil dari Bartlett's Test of Sphericity (Sig.) dimana dalam gambar 4.19 diatas menunjukan bahwa nilainya adalah 0.011 dimana dalam metode analisis faktor, persyaratan nilai Bartlett's Test of Sphericity (Sig.) adalah lebih kecil dari 0.050, maka langkah perhitungan selanjutnya dapat dilanjutkan.

\begin{tabular}{|c|c|c|c|c|c|c|c|}
\hline \multicolumn{8}{|c|}{ Anti-image Matrices } \\
\hline & & Manusia & $\begin{array}{l}\text { Profesionalita } \\
\text { s Menejemen }\end{array}$ & $\begin{array}{c}\text { Desain \& } \\
\text { Dokumentasi }\end{array}$ & Material & Pelaksanaan & Kendala Luar \\
\hline \multirow[t]{6}{*}{ Anti-image Covariance } & Manusia & .397 & .015 & -.078 & -.272 & .087 & .117 \\
\hline & $\begin{array}{l}\text { Profesionalitas } \\
\text { Menejemen }\end{array}$ & .015 & .832 & .172 & .089 & -.142 & -.125 \\
\hline & Desain \& Dokumentasi & -.078 & .172 & .560 & -.109 & .209 & -102 \\
\hline & Material & -.272 & -.089 & -109 & 403 & .079 & .089 \\
\hline & Pelaksanaan & .087 & -.142 & .209 & -.079 & .715 & 142 \\
\hline & Kendala Luar & .117 & -125 & -.102 & -.089 & .142 & .889 \\
\hline \multirow[t]{6}{*}{ Anti-image Correlation } & Manusia & $.610^{2}$ & .026 & -.164 & -.680 & .163 & .196 \\
\hline & $\begin{array}{l}\text { Profesionalitas } \\
\text { Menejemen }\end{array}$ & .026 & $.558^{\mathrm{a}}$ & .252 & -.154 & -.184 & -.145 \\
\hline & Desain \& Dokumentasi & -164 & .252 & $.745^{\mathrm{a}}$ & -.228 & .331 & -144 \\
\hline & Material & -.680 & -.154 & -.228 & $.581^{a}$ & -.148 & -.149 \\
\hline & Pelaksanaan & .163 & -.184 & 331 & -148 & $.663^{a}$ & .178 \\
\hline & Kendala Luar & .196 & -.145 & -.144 & -.149 & .178 & $.414^{a}$ \\
\hline
\end{tabular}

Gambar 3. Hasil Anti-Images Matrices

Setelah semua hasil perhitungan nilai Kaiser Meyer Olkin Measure of Sampling Adequacy (KMO-MSA) dan Bartlett's Test of Sphericity (Sig.) maka langkah selanjutnya adalah perhitungan dari Anti-Image Matrices. Dalam uji ini akan diketahui dari keenam variabel penelitian, variabel mana saja yang layak untuk dipakai dalam metode analisis faktor. Hal tersebut dapat diketahui dengan melihat nilai Anti-image Correlation. Pada gambar 4.20 diatas terdapat kode huruf (a) yang artinya tanda untuk Measure of Sampling Adequacy (MSA). Diketahui nilai MSA dari masing-masing variabel penelitian adalah sebagai berikut:

1. Manusia sebesar 0.610

2. Profesionalitas Menejemen sebesar 0.558

3. Desain dan Dokumentasi sebesar 0.745 
4. Material sebesar 0.581

5. Pelaksanaan sebesar 0.663

6. Kendala Luar sebesar 0.414

Dari keenam nilai diatas dalam syarat analisis faktor nilai MSA harus lebih besar dari 0.50 , maka dari data diatas, variabel Kendala Luar nilai MSA nya tidak memenuhi syarat, oleh karena itu perhitungan harus dilakukan kembali dengan menghilangkan variabel Kendala Luar. Atau dengan kata lain variabel Kendala Luar tidak dapat mewakili faktor penyebab waste material besi beton.

Sehingga setelah perhitungan ulang tanpa memasukan variabel kendala luar maka akan hasil perhitungan dapat dirangkum sebagai tabel dibawah ini

Tabel 3. Hasil Analisis Faktor

\begin{tabular}{cccc}
\hline $\begin{array}{c}\text { Faktor yang } \\
\text { terbentuk }\end{array}$ & Variabel & Loading Factor & Percent of Variance \\
\hline \multirow{2}{*}{ Faktor 1 } & Manusia & 0.894 \\
\cline { 2 - 3 } & Desain dan Dokumentasi & 0.597 & $47.791 \%$ \\
\hline \multirow{2}{*}{ Faktor 2 } & Profesionalitas Menejemen & $\mathbf{0 . 9 2 4}$ & $25.141 \%$ \\
\cline { 2 - 3 } & Pelaksanaan & $\mathbf{0 . 8 1 0}$ & \\
\hline
\end{tabular}

Dari semua hasil perhitungan program SPSS dengan menggunakan metode analisis faktor, diperoleh bahwa dari keenam variabel (Manusia, Profesionalitas Menejemen, Desain dan Dokumentasi, Material, dan Kendala Luar) yang menyebabkan waste material besi beton, terbentuklah 2 faktor konstrak yaitu yang pertama ada faktor 1 (Manusia, Desain dan Dokumentasi, dan Material) dan faktor 2 (Profesionalitas Menejemen dan Pelaksanaan). Dimana pengelompokan variabel-variabel kedalam sebuah faktor yang baru didasari dari nilai korelasi antar variabel maupun antar faktor.

Dan dapat dilihat pula bahwa dalam hasil ahkir ini variabel Kendala Luar tidak masuk kedalam kelompok faktor 1 maupun faktor 2. Hal ini disebabkan karena pada saat pengujian nilai Anti-Image Matrices nilai Measure of Sampling Adequacy (MSA) sebesar 0.414 dan tidak melebihi nilai syarat yaitu 0.50 sehingga dapat dikatakan bahwa hasil kuesioner dari variabel Kendala Luar tidak memberikan pengaruh besar terhadap penyebab waste material besi beton.

Dilihat kembali pada tabel 2. diatas dapat dikatakan bahwa dari 2 faktor yang terbentuk, kedua faktor tersebut dapat menjelaskan $72.932 \%$ varians dari hasil kuesioner penelitian. Sedangakan $27.068 \%$ sisanya adalah informasi yang terhilang atau tidak dapat dijelaskan. Faktor yang paling dominan adalah faktor 1 karena memiliki nilai Percent of Variance paling tinggi yaitu $47.791 \%$.

\section{KESIMPULAN DAN SARAN}

\section{Kesimpulan}

Berdasarkan analisis dan hasil perhitungan dari data-data penelitian waste material besi beton ini, maka disimpulkan bahwa:

1. Dari perhitungan 10 sampel proyek low rise building di daerah Jakarta dan sekitarnya, diperoleh bahwa angka rata-rata persentase volume waste material besi beton adalah $4.384 \%$ dimana angka terendahnya adalah $2.01 \%$ dan angka tertingginya adalah $6.96 \%$.

2. kerugian waste material besi beton paling besar terjadi pada Proyek Pembangunan rumah tinggal 2 lantai Sunter yaitu sebesar Rp 12.441.633,18. Sementara angka terendah terlihat pada Proyek Town House Sinar Indah 1 sebesar Rp 804.811,15. Dari data tabel kerugian waste diatas dapat disimpulkan bahwa ada 3 proyek low rise building yang angka kerugian waste nya kecil yaitu pada Proyek Town House Sinar Indah 1, 2, dan 3. Hal ini dapat terjadi karena adanya menejemen waste dan pengawasan terhadap waste yang baik.

3. Ada 2 (dua) faktor penyebab waste material besi beton yang terbentuk setelah dianalisis menggunakan metode analisis faktor, yang pertama adalah faktor Human error dalam menangani material besi beton. 
Faktor yang kedua adalah manajemen pelaksanaan konstruksi. Faktor yang paling berperan besar adalah faktor 1 yaitu Human error.

\section{Saran}

1. Dalam penelitian ini besar persentase volume waste material besi beton yang diperoleh nilainya lebih besar dari contoh penelitian waste sebelumnya, ini menandakan bahwa kesadaran akan waste material besi beton masih perlu diperhatikan dan dikontrol lebih baik lagi.

2. Kerugian waste yang diteliti dalam penelitian ini berupa kerugian biaya, maka disarankan untuk penelitian selanjutnya dapat ditinjau kerugian waste dari segi waktu.

3. Dari hasil penelitian diperoleh faktor yang menyebabkan waste material besi beton terbesar adalah Manusia, Desain \& Dokumentasi, dan Material, maka disarankan pada penelitian selanjutnya membahas lebih dalam tentang hal ini.

4. Waste yang diteliti dalam penelitian ini adalah waste material besi beton, maka disarankan pada penelitian selanjutnya waste yang diteliti berupa waste non material seperti non-value adding activities.

\section{DAFTAR PUSTAKA}

Adlin, R.A., Nursyamsi, Rambe, A.P. "Analisa waste material konstruksi dengan aplikasi metode lean construction." Universitas Sumatera Utara. 2017.

Ganesan, S. "Employment Technology and Construction Development”. Ashgate Publishing Company. 2000.

Muhwezi, L., Chamuriho, L.M., Lema, N.M. "An investigation into Materials Waste on Building Construction Projects in Kampala.” ISSN: 2276-8955. 2012.

Waty, M., dkk. "Modeling of Waste Material Cost on Road Construction Projects". International Journal of Engineering \& Technology. 2018 : 474-477. 
Studi Analisis Persentase Waste Besi Beton dan Faktor

Liem Antonio Geraldi, et al.

Penyebabnya pada Bangunan Bertingkat rendah di Jakarta 